\title{
INDIRECT FLUORESCENT ANTIBODY TEST IN DIAGNOSIS OF TRICHINELLOSIS IN MAN
}

\author{
K. CHROUST and T. MITTERMAYER* \\ State Veterinary Institute, 46311 Vratislavice n. N., *Clinic \\ of Infectious Diseases, Faculty Hospital, Košice \\ Received fanuary 4, 1983
}

\begin{abstract}
Chroust K., Mittermayer T.: Indirect Fluorescent Antibody Test in Diagnosis of Trichinellosis in Man. Acta vet. Brno, 52, 1983: 177-181.

To demonstrate the presence of antibodies during the six trichinellosis epidemics in humans in the east Slovakia in 1971-1980 the indirect fluorescent antibody test (IFA), the microprecipitation reaction (MP) and the complement fixation reaction (CF) were employed.

The IFA test proved to be very sensitive and out of all serologic tests used it yielded standardly the most reliable results. From the total number of 293 serums of trichinous meat consumers that IFA test was used in 274 serums and yielded positive results in $85.3 \%$. The MP reaction was employed in 144 and CF reaction in 109 cases giving 48.6 and $45.2 \%$ of positive results, resp.

Using the IFA test, the antibodies were found even in cases when very small amount of trichinous meat had been consumed and the apparent manifestation of the disease did not appear. The reaction was found to be applicable even for the detection of latent cases of trichinellosis in humans.
\end{abstract}

T. spiralis, antibodies in humans, indirect fluorescent test, microprecipitation reaction, complement fixation reaction.

From the epidemiological and epizootiological aspects trichinellosis is still the helminthiasis of primary significance in worldwide dimensions. As examinations from last years have shown, the number of positive cases in humans is still high. On post-mortem examination of diaphragm in some states of the USA, in Canada and Mexico the trichinellosis was detected in 5-23\%, the percentage of cases found in some European countries being also high, e. g. $4-15 \%$ in the USSR, 4-13\% in Poland, $0.4-5.2 \%$ in Great Britain, $0.8-2.4 \%$ in Hungary (Lupascu 1970). Chroust (1961) using the literature data has found that in Bohemia and Moravia the trichinellosis epidemic up to the year 1951 has occurred 35 times. Mittermayer (1973) reported that in the east Slovakia six trichinellosis epidemics in humans were detected in the period 1933 to 1970 . On the basis of the post-mortem trichinoscopic examination of diaphragm of 182 patients that died from various diseases this author found T. spiralis in 1966 in 12 cases, i. e. in $6.58 \%$. Further epidemics of trichinellosis in humans in the east Slovakia were reported by Mittermayer et al. (1976, 1978, 1981).

As was shown by Hovorka (1957), Mituch (1961), Chroust (1961) and Dyková (1965) free living carnivores, mostly foxes, lynxes, wolves and wild cats, have practical epizootiological significance for the trichinellosis spreading in our conditions.

The main epizootiological importance, as far as the invasion of humans in our conditions is concerned, is ascribed to wild boars whose meat is consumed usually at the place of shooting and is often not subject to a compulsory delivery and thus escapes even a parasitological examination.

At present, a considerable attention has been devoted to the diagnosis of trichinellosis. It turns out that the more precise the diagnostic methods are, the more often we detected the co-called latent cases of the disease that previously escaped our attention.

The fluorescent method in the study of antigenous properties of larvae and grown $T$. spiralis parasites was firstly used by Jacks on and Lewert (1957) and Jackson (1959). Indirect fluorescent 
test in laboratory diagnostics was used by Sadun (1963), Baratawidjaja et al. (1963), Sulzer (1965), Labzoffsky et al. (1964), Sulzer and Chrisholm (1966), Engelbrecht (1966), Ruittenberg et al. (1967), Chroust et al. (1966), Chroust and Dubanský (1967; 1970), Kozar (1968), Uhlíková and Zástěra (1968) and others.

\section{Materials and Methods}

For the purpose of intravital serologic diagnosis of human trichinellosis the applicability of the indirect fluorescent (IFA) test for the examination of blood serum of patients from the six trichinellosis epidemics in the east Slovakia during 1971-1980 has been checked.

The first epidemic, in which serums were examined, was detected in 1971 and in three persons out of 54 consumers of trichinous meat from wild boar the disease manifested itself. These three persons had a serious acute form of the disease because they repeatedly ate wild boar meat from which meat products were prepared. Other patients consumed in addition to roasted and stewed also home-prepared canned meat. The latter was thermally treated but not sufficiently since upon the examination of this canned meat living $T$. spiralis larvae were found. From the mentioned epidemic 44 persons were examined using the microprecipitation (MC) reaction and complement fixation (CF) reaction and 38 serums of patients by the IFA test.

During the epidemic in 1974 wild boar meat infected with $T$. spiralis was consumed by 74 persons. The meat was consumed in various forms, raw as well as thermally treated. By the examination using both the compression and digestion methods the infestation of meat was found in smoked sausages. In 20 persons the disease was manifest, in two trichinellosis was verified by the positive muscle biopsy. Serologically 65 serums were examined by the MP and CF reactions and 72 serums by the IFA test.

In the third epidemic in 197510 persons were affected, in 7 of them with clinical manifestation. The patients consumed raw smoked meat products from a home-grown pig which was subjected neither to veterinary food inspection nor to trichinoscopic examination at slaughter. The diagnosis was verified by the detection of the parasite in meat products and also using muscle biopsy technique in one patient. Serological examination was carried out in 9 patients using the IFA and MP tests.

The fourth epidemic was detected in 1976-1977. Also in this case undercooked wild boar meat caused the disease manifesting itself in 10 from 26 consumers. In two of the patients neurotic syndroms were observed during the course of the disease, in 16 persons the form being latent. Serums of all consumers were examined by the IFA and MC test.

The fifth epidemic was observed in 1979. In 3 patients the disease was manifested, in 26 in inapparent form. Also in this case wild boar meat, consumed raw, smoked or undercooked, was the cause of the infestation. Serums of all 29 patients were examined by the IFA test.

The sixth epidemic was detected in 1980 when in 41 persons the disease was manifested, in 46 being inapparent. Here again wild boar meat consumed by 100 persons was the source of the invasion. All serums were examined by the IFA test.

In the examination of human serum the IFA test was used according to Chroust and Dubanský (1970) who used this method in diagnosis of trichinellosis in experimentally infested laboratory animals. The MP reaction was carried out according to Roth (1941), the CF reaction according to usual laboratory methods.

\section{Results}

In six trichinellosis epidemics that appeared in the period $1971-1980$ in the east Slovakia 279 patient serums were examined, 144 serums by the MP reaction, 109 by the CF reaction and 274 by the IFA test. The total number of serums and the results of their examination are given in Table 1. Out of 293 consumers of trichinous meat the disease was manifested in 85 persons, the inapparent form being detected in 182 persons. By the IFA test altogether 78 serums of patients with manifest form were examined, 77 of them were found to be positive $(98.7 \%)$ and 182 inapparent. From the latter, 146 cases were positive $(80.2 \%)$. The levels of titers found in the examination of patients with manifest form and in patients with inapparent form of the disease are given in Table 2 and 3, resp. 
From the total number of the serums examined the IFA test was positive in $85.3 \%, M C$ reaction in $48.6 \%$ and $\mathrm{CF}$ reaction in $45.2 \%$.

Table 1

Results of individual serological reactions with serums of patients in six trichinellosis epidemics in the period 1971-1980

\begin{tabular}{|c|c|c|c|c|c|c|c|c|c|}
\hline \multirow{2}{*}{$\begin{array}{l}\text { Year of } \\
\text { epidemic }\end{array}$} & \multirow{2}{*}{$\begin{array}{l}\text { Number of } \\
\text { consumers of } \\
\text { trichinous meat }\end{array}$} & \multirow{2}{*}{$\begin{array}{l}\text { Number of } \\
\text { patients } \\
\text { with mani- } \\
\text { fest form }\end{array}$} & \multirow{2}{*}{$\begin{array}{l}\text { Number of } \\
\text { patients } \\
\text { with latent } \\
\text { form }\end{array}$} & \multicolumn{3}{|c|}{$\begin{array}{l}\text { Number of patients } \\
\text { examined by }\end{array}$} & \multicolumn{3}{|c|}{$\%$ of positive cases } \\
\hline & & & & MC & CF & IFA & $\mathrm{MC}$ & $\mathrm{CF}$ & IFA \\
\hline $\begin{array}{c}1971 \\
1974 \\
1975 \\
1976-1977 \\
1979 \\
1980\end{array}$ & $\begin{array}{r}54 \\
74 \\
10 \\
26 \\
29 \\
100\end{array}$ & $\begin{array}{r}3 \\
20 \\
7 \\
10 \\
3 \\
37\end{array}$ & $\begin{array}{r}34 \\
45 \\
3 \\
16 \\
15 \\
33\end{array}$ & $\begin{array}{r}44 \\
65 \\
9 \\
26 \\
- \\
-\end{array}$ & $\begin{array}{l}44 \\
65 \\
- \\
- \\
- \\
-\end{array}$ & $\begin{array}{r}38 \\
72 \\
9 \\
26 \\
29 \\
100\end{array}$ & $\begin{array}{l}68.2 \\
24.6 \\
55.5 \\
46.1 \\
- \\
-\end{array}$ & $\begin{array}{c}65.9 \\
24.6 \\
= \\
= \\
-\end{array}$ & $\begin{array}{l}93.7 \\
86.1 \\
100 \\
100 \\
62.1 \\
70\end{array}$ \\
\hline
\end{tabular}

Table 2

Results of in the IFA test used on serum of patients with manifest form in the individual epidemics

\begin{tabular}{|c|c|c|c|c|c|c|c|c|}
\hline \multirow{2}{*}{$\begin{array}{c}\text { Year of } \\
\text { epidemic }\end{array}$} & \multirow{2}{*}{$\begin{array}{l}\text { Number of } \\
\text { serums } \\
\text { examined }\end{array}$} & \multirow{2}{*}{$\begin{array}{l}\text { Number of } \\
\text { positive } \\
\text { serums }\end{array}$} & \multicolumn{6}{|c|}{ Number of positive serums diluted in the ratio } \\
\hline & & & $1: 8$ & $1: 16$ & $1: 32$ & $1: 64$ & $1: 128$ & $1: 512$ \\
\hline $\begin{array}{c}1971 \\
1974 \\
1975 \\
1976-1977 \\
1979 \\
1980\end{array}$ & $\begin{array}{r}3 \\
20 \\
7 \\
10 \\
3 \\
42\end{array}$ & $\begin{array}{r}3 \\
20 \\
7 \\
10 \\
3 \\
37\end{array}$ & $\begin{array}{l}\overline{1} \\
\overline{-} \\
\overline{-} \\
4\end{array}$ & $\begin{array}{c}- \\
-4 \\
\frac{3}{9}\end{array}$ & $\begin{array}{c}\overline{2} \\
\frac{1}{1} \\
\overline{15}\end{array}$ & $\begin{array}{l}- \\
2 \\
2 \\
2 \\
1 \\
9\end{array}$ & $\begin{array}{l}- \\
3 \\
3 \\
2 \\
2 \\
1\end{array}$ & $\begin{array}{l}3 \\
8 \\
2 \\
2 \\
- \\
-\end{array}$ \\
\hline
\end{tabular}

Table 3

Results of the IFA test used on serums of patients with latent form in the individual epidemics

\begin{tabular}{|c|c|c|c|c|c|c|c|c|}
\hline \multirow{2}{*}{$\begin{array}{l}\text { Year of } \\
\text { epidemic }\end{array}$} & \multirow{2}{*}{$\begin{array}{c}\text { Number of } \\
\text { serums } \\
\text { examined }\end{array}$} & \multirow{2}{*}{$\begin{array}{c}\text { Number of } \\
\text { positive } \\
\text { serums }\end{array}$} & \multicolumn{6}{|c|}{ Number of positive serums diluted in the ratio } \\
\hline & & & $1: 8$ & $1: 16$ & $1: 32$ & $1: 64$ & $1: 128$ & $1: 512$ \\
\hline $\begin{array}{c}1971 \\
1974 \\
1975 \\
1976-1977 \\
1979 \\
1980\end{array}$ & $\begin{array}{r}35 \\
54 \\
3 \\
16 \\
26 \\
48\end{array}$ & $\begin{array}{r}34 \\
45 \\
3 \\
16 \\
15 \\
33\end{array}$ & $\begin{array}{r}4 \\
16 \\
1 \\
9 \\
10 \\
22\end{array}$ & $\begin{array}{r}5 \\
11 \\
1 \\
4 \\
3 \\
10\end{array}$ & $\begin{array}{r}9 \\
10 \\
1 \\
2 \\
2 \\
1\end{array}$ & $\begin{array}{l}6 \\
8 \\
-1 \\
- \\
-\end{array}$ & $\begin{array}{l}8 \\
- \\
- \\
- \\
-\end{array}$ & $\begin{array}{l}2 \\
- \\
- \\
- \\
-\end{array}$ \\
\hline
\end{tabular}

\section{Discussion}

On the basis of the results reported in the previous studies (Chroust and Dubanský 1967 and 1970) we have used the IFA test in order to demonstrate trichinous antibodies in humans. Fluorescence intensity of the body and the cuticles of $T$. spiralis larvae, and possibly the presence of precipitates in natural openings of larvae or on other body places that expressively fluoresce, were regarded as the main criterion for the evaluation of the reaction.

Using the IFA test it was possible to demonstrate antibodies practically in all manifest cases of trichinellosis. E. g. in the 1971 epidemic the IFA test was found to be positive in 37 out of 38 examined serums of patients $(93.7 \%)$, 
whereas the MP and CF reactions were positive in 68.2 and $65.9 \%$, resp. Even more evident differences were observed in the 1974, 1975 and 1976-1977 epidemics when the IFA test was positive in 86.1 - $100 \%$ whereas the MP test only in $24.6,55.5$ and $46.1 \%$ and in the case of the CF reaction it was as little as $24.6 \%$ (see Table 1). In the epidemics of 1979 and 1980 the examination was carried out using only the IFA test. In all manifest forms of trichinellosis the positivity was found in $100 \%$ of cases. In inapparent forms, however, the positivity was not detected in all cases, the percent of it in consumers of trichinous meat being 62.1 and $70 \%$ in 1979 and 1980, resp.

The results of the comparison of all three serological methods have shown high sensitivity of the indirect fluorescent antibody test by which altogether $85.3 \%$ of positive results was obtained whereas in the case of microprecipitation and complement fixation reactions it was found to be 48.6 and $45.2 \%$, resp. These results are in accordance with the findings of other authors that carried out serological examination of persons with trichinellosis (Sadun et al. 1962; Labzoffsky et al. 1964, Sulzer and Chrisholm 1966, Kozar 1968 and others).

\section{Nepřímá imunofluorescenční reakce $\mathrm{v}$ diagnostice trichinelózy u lidí}

$\mathrm{K}$ průkazu protilátek $\mathrm{v}$ průběhu šesti epidemií trichinelózy lidí na východním Slovensku v letech $1971-1980$ byla použita nepřímá imunofluorescenční reakce (NIFR), mikroprecipitační reakce (MPR) a reakce vazby komplementu (RVK).

Neprímá imunofluorescenční reakce se ukázala jako velmi citlivá a $\mathrm{z}$ použitých sérologických metod dávala standardně nejspolehlivějši výsledky. $\mathrm{Z}$ celkového počtu 293 sér konzumentů trichinelózního masa byla NIFR použita u 274 sér a dala pozitivní výsledky v $85,3 \%$, MPR byla použita ve 144 př́ipadech a dala $48,6 \%$ pozitivních výsledků a RVK ve 109 prípadech a dala 54,2 \% pozitivních výsledků.

Pomocí NIFR byly prokázány protilátky i $\mathrm{v}$ prrípadech, kdy šlo o konzumaci velmi malého množství trichinelózního masa a konzumenti ještě zjevně neonemocněli. Reakce je použitelná i pro vyhledávání latentních př́ipadů trichinelózy u lidí.

Косвенная иммунофлюоресцентная реакция в диагностике трихинеллеза у людей

Для определения антител в ходе шести эпидемий трихинеллеза у больных в восточной Словакии в 1971-1980 гг. была использована косвенная иммунофлюоресцентная реакция [NIFR], микропреципитационная реакция (MPR) и реакция связи комплемента (RVK).

Косвенная иммунофлюоресцентная реакция оказалась весьма чувствительной и из числа использованных сывороточных методов отличалась стандартно самыми надежными результатами. Из 293 потребителей трихинеллезного мяса косвенная иммунофлюоресцентная реакция была использована у 274 сывороток с положительными результатами в $85,3 \%$, микропреципитационная реакция была использована в 144 случаях с 48,6 \% положительных результатов и реакция связи комплемента - в 109 случаях с 45,2 \% положительных результатов. 
С помощью косвенной иммунофлюоресцентной реакции были установлены антитела даже в тех случаях, когда речь шла о потреблении небольшого количества трихинеллезного мяса и у потребляющих мясо людей не наблюдалось явное заболевание. Реакция применима также для поисков скрытых случаев трихинеллеза у людей.

\section{References}

BARATAWIDJAJA, R. K. - HEWSON, A. - LABZOFFSKY, N. A.: Fluorescent Antibody Staining in the Serodiagnosis of Trichinosis. Canad. J. Microbiol., 9, 1963: 625.

ENGELBRECHT, E.: Diagnosis of recent and long standing Trichinella spiralis infections by means of the immunofluorescence test. Arch. roun. Path. exp. Microbiol., 25, 1966: 831-848.

HOVORKA, J.: Przycynek do wykrywania ognisk Trichinella spiralis $\mathrm{v}$ naturalnych warunkach Slowacji v ČSR. Wiad. Parazyt., 3, 1957: 231-236.

CHROUST, K.: Svalovec stočený (Trichinella spiralis) u divoce žijících masožravců. Thesis VF Brno, $1961 ; 89$ pp.

CHROUST, K. - DUBANSKÝ, V. - PISKAČ, A.: Fluorescent-Antibody Studies of Muscle Larvae Trichinella spiralis (Owen, 1835). I. The Direct Fluorescent-Antibody Method. Sbor. VŠZ, řada B (Brno), 35, 1966: 505-514.

CHROUST, K. - DUBANSKY, V.: Fluorescent Antibody Studies of Muscle larvae Trichinella spiralis (Owen, 1835). II. The Indirect Fluorescent:-Antibody Method. Sborník VŠZ, řada B (Brno), 36, 1967: 299-305.

CHROUST, K. - DUBANSKÝ, V.: The indirect fluorescent antibody method in experimental trichinosis diagnostic. Acta vet. Brno, 39, 1970: 157-163.

JACKSON, G. J.: Fluorescent antibody studies of Trichinella spiralis infection. J. Inf. Dis., 104, 1959: $97-117$.

KAGAN, I. G.: Trichinosis: A review of biologic, serologic and immunologic aspects. J. Inf. Dis., 107, 1960: 65-93.

KOZAR, Z. - KOZAR, M.: Dynamics and persistence of antibodies in trichinellosis. Wiad. Parazytol., 14, 1968: 171-185.

LABZOFFSKY, N. A. - BARATAWIDJAJA, R. K. - KUITUNEN, E. - LEWIS, F. N. KAVELMAN, D. A. - MORRISEY, L. P.: Immunofluorescence as an aid in the early diagnosis of trichinosis. Canad. Med. Ass. J., 90, 1964: 920-921.

LUPASCU, CH.: Trichineloza. Edit. ARSR, Bucuresti, 1970: 96.

MITTERMAYER, T.: K problematike trichinelózy na východním Slovensku. Prakt. lék., 53, 1973: 15- 18 .

MITTERMAYER, T. - CHROUST, K. - DEDINA, L. - MICHNA, J.: Klinické a epidemiologické poznatky z epidémie trichinelózy u ludí v okrese Košice v r. 1971. Brat. lek. listy, 66, 1976: $217-221$.

MITTERMAYER, T. - CHROUST, K. - DEDINA, L. - ŠIMUNOVÁ, M.: Poznatky ku klinike a terapii trichinelózy liečenej thiabendazolom a mebendazolom. Čas. lék. čes., 117, 1978: $1053-1056$.

MITTERMAYER, T. - LIBOVÁ, E. - CHROUST, K. - SUCHÁNOVÁ, T.: Klinicko-epidemiologická charakteristika epidémie trichinelózy v r. 1979 v okrese Prešov s terapeutickou aplikáciou mebendazolu. Brat. lek. listy, 75, 1981: 466-472.

MITUCH, J.: Stav trichinelózy u volne žijúcich zvierat na Slovensku. Výhledy semin. pro doškol. vet. lék., Pardubice, 6, 1961: 44.

ROTH, H.: The in vitro action of Trichinella larvae in immune serum - a new precipitin test in trichinellosis. Acta Path. et Microb. Scand., 43, 1941: 160-168.

RUITENBERG, E. - KAMPELMACHER, E. H. - BERKVENS, J.: Die indirecte fluorescierende Antikörpertechnik bei Serodiagnostik von mit Trichinella spiralis-infizierten Schweinen. Fleischwirtschaft, 47, 1967: $1217-1220$.

SADUN, E. H.: Seminar on immunity to parasitic helminths. VII. Fluorescent Antibody technique for Helminth Infections. Exper. Parasitol., 13, 1963: 72-82.

SULZER, A. J.: Indirect fluorescent antibody test for parasitic diseases. I. Preparation of stable antigen from larvae of Trichinella spiralis. J. Parasitol, 51, 1965: 717-721.

SULZER, A. J. - CHISHOLM, E. S.: Comparison of the IFA and other tests for T. spiralis antibodies. Publ. Health Rep., 81, 1966: 729-734.

UHLÍKOVÁ, M. - ZÁSTĚRA, M.: Fluorescent Antibody Technique for the Serodiagnosis of Trichinellosis. Folia Parasiol., Praha, 15, 1968: 243-251. 